\title{
Preliminary study on bird community assemblage and feeding guild in forest and developed areas of Muallim, Perak, Peninsular Malaysia Noraine Salleh Hudin ${ }^{1}$, Hasimah Bachu ${ }^{1}$, Ahmad Humaidi Hairuman', Suci Ferdiana ${ }^{2}$, Gelaye Gebremichael ${ }^{3}$
}

\author{
${ }^{1}$ Biology Department, Faculty of Science and Mathematics, \\ Sultan Idris Education University \\ ${ }^{2}$ Nutrition Department, Surabaya Health School, Jl. Medokan Semampir Indah No.27, \\ Medokan Semampir, Kec. Sukolilo, Kota SBY, Jawa Timur, Indonesia \\ ${ }^{3}$ College of Natural Sciences, Jimma University, PO Box 378, Jimma, Ethiopia \\ *Corresponding author : noraine@fsmt.upsi.edu.my
}

Received: 11 November 2019; Accepted: 12 December 2019; Published: 18 December 2019

\begin{abstract}
We investigated bird species richness and feeding guilds in two contrasting habitat types i.e. forest and developed areas in Muallim district of Perak, Peninsular Malaysia. Field surveys were conducted by using point-count observation along transects and mist-netting methods to determine the presence of bird species in the forest and developed areas. There were 28 species of birds from 23 families found in these habitats, where 13 species were found in forest and 15 species in the developed areas. The species richness was similar between forest and urbanized habitats. Forest birds were mainly frugivores and frugivore-insectivores whereas those from developed areas were insectivore-granivores and insectivores. Insects are important food resources in both habitats. Our results suggest that the availability of food resources in a locality may partly influence the community structure of Avifauna where conversion of forest into developed areas may induce shifts in the distribution of feeding guilds and the presence of species within the area. While developed areas have the capacity to support bird community, species that are specialized to forests may still be affected by the habitat change. Our study provides preliminary ideas on how bird communities in the tropical region are being shaped in response to urbanization. Further studies should cover a wider geographical range and over a longer period of surveys to yield a better understanding on this issue.
\end{abstract}

Keywords: Sustainability, biodiversity, urbanization, diet, niche

\section{INTRODUCTION}

Human activities have induced changes in land cover, global climate, and biodiversity at extraordinary rates. One of the most drastic forms of land-use alteration is caused by urban development where natural environments are altered through substitution of native flora by built structures, displacement of natural resources by the artificial ones and a higher intensity of human disturbances [1]. Land development is occurring at accelerating pace across the globe and, at present, $0.5-3.0 \%$ of the terrestrial areas on the earth has already been converted into urban ecosystems [2]. This growth is expected to continue in the future and forecast showed that by 2030 urbanized land cover will increase up to 1.2 million $\mathrm{km}^{2}$, almost tripling its size in 2000 [3].

The impacts of urban development vary with the speed and intensity of environmental changes, and the common consequence is decrease in species richness as observed in mammals, reptiles, birds, amphibians, invertebrates, and plants [4]. At the same time, non-native species may replace the local ones and increase in abundance in local environments [4]. These species are not only less affected by the urbanization processes, 
instead, they view developed environments as ecological opportunities [5]. These urban-related species have the ability to exploit urban resources, although they can still continue to utilize natural resources or become fully dependent on anthropogenic resources .

Considering the worldwide occurrence of land development, science is challenged with the needs to predict how developed environments affect species. During the last two decades, numbers of studies have attempted to identify traits that allow survival in developed environments in order to predict future animal species compositions following urbanization processes. However, those studies were mainly based in Europe and Northern America [6]. Despite the fact that land development occurs at the highest rate in South East Asia and Africa [6], the scarcity of knowledge on how tropical animals respond to developed environment raised the needs for more studies in tropical regions.

Therefore, we aimed to explore how animal community are being affected by urbanization. To address this issue, we compared species richness at two contrasting habitats i.e. forest vs. developed areas. We used bird species as the model organism since birds are relatively conspicuous and thus fairly easy to survey. Furthermore, birds are excellent indicators for assessing habitat quality and environmental change [7]. In order to understand how the bird communities are being shaped by their local environment, we also aimed to relate the occurrence of species at the different habitats with the feeding guild of each species.

\section{METHODOLOGY}

\section{Study sites}

This study was conducted in Muallim, a district located in the south of the Perak State of Peninsular Malaysia. Situated in the southern part of Muallim, the sampling sites consisted of two different habitat types which were Behrang Forest Reserve (BFR) and developed areas of Tanjung Malim. BFR is classified as Production Forest by the Forestry Department of Peninsular Malaysia which represents a protected area with sustainable use of natural resources under the Type IV IUCN category [8]. It is composed largely by highlands of the Titiwangsa Range on its eastern border where the highest elevation is as high as $1229 \mathrm{~m}$ above sea level. Our study site at BFR was located between $230 \mathrm{~m}$ and $420 \mathrm{~m}$ above sea level. Meanwhile, the developed areas of Tanjung Malim represented a small town characterized by low-rise residential buildings, schools, and university campuses. Vegetation in these areas were mainly ornamental plants and fruit trees planted by local communities in their yards. This town is the closest developed areas to the BFR whereby the distance between the two sites was approximately $14 \mathrm{~km}$. 


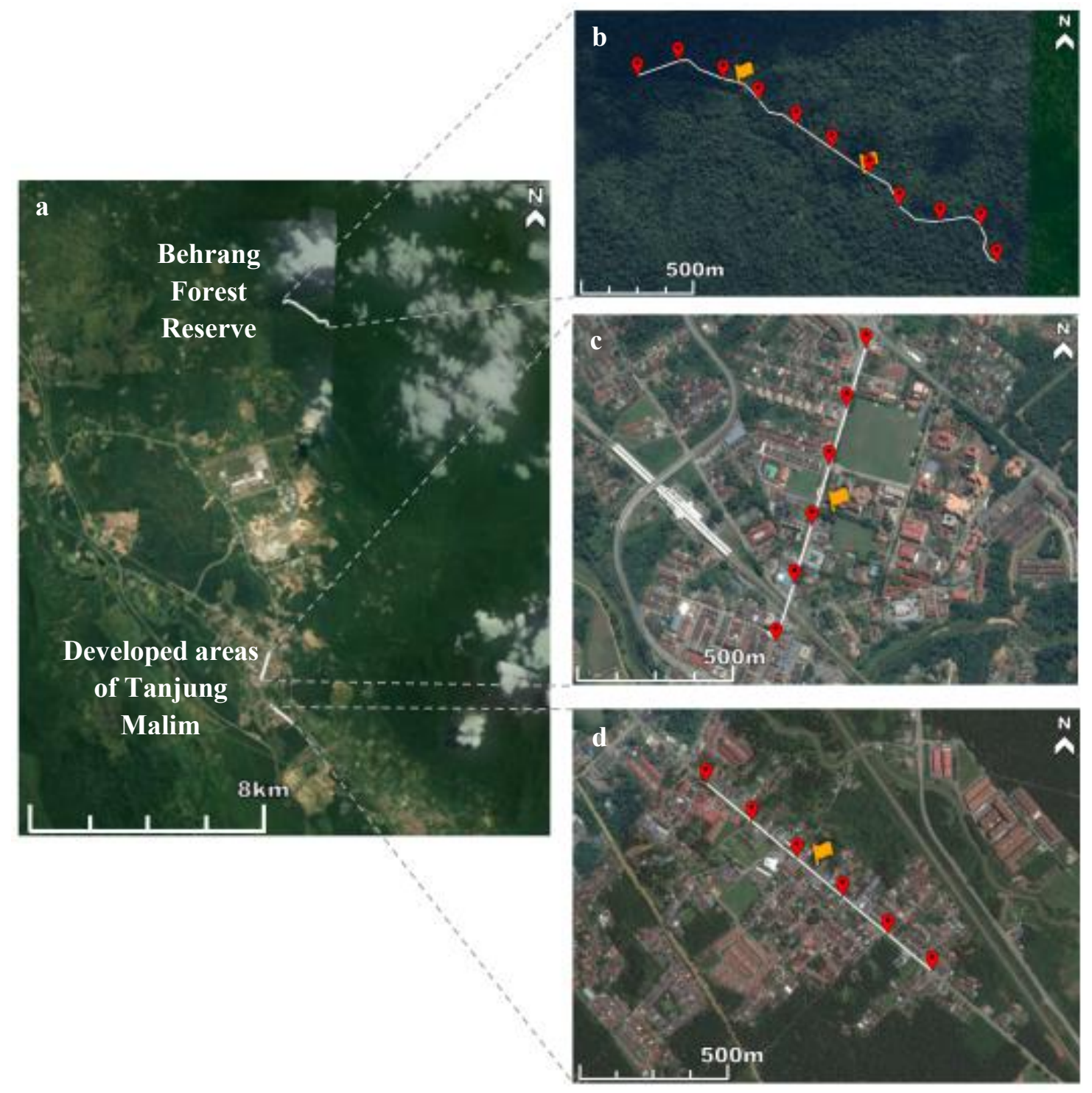

Figure 1. a) Locations of study sites in Muallim, Perak. b) Transect (2 km) at Behrang Forest Reserve; c) and d) Transects (1 km each) at developed areas of Tanjung Malim.

Prepresents bird observation points (200 m apart) while represents location of mist net placement.

\section{Field survey}

Bird species survey was done between 25-28 January 2019 in BFR and 15-19 April 2019 in developed areas of Tanjung Malim along line transects that totaling $2 \mathrm{~km}$ distance at each sampling site (Figure 1). The point count method was applied where birds were observed for 10 minutes at every $200 \mathrm{~m}$ intervals along the transects. The observations were done during birds' most active hours within a day i.e. between 0700 - 1000 and $1700-1900$ hours. We surveyed the birds based on visual observation using $8 \times 40$ binoculars, vocalization and mist-netting. Bird vocalization was recorded using Rode shotgun microphone and recorder. Identification of bird species based on vocalization was done on field by a bird expert while those unidentified were recorded and examined using digital sound collection [9]. Two mist nets were set up at both BFR and developed areas (Figure 1) whereby these nets were let open between $0700-1000$ and $1700-1900$ hours and were checked for every 2 hours. During the survey, any birds seen, heard and captured were recorded. Birds observed and captured were identified for their species based on $[10,11,12]$. The captured birds were immediately released into their habitats after the identification process. 


\section{Feeding guild, conservation status, and protection status}

For each identified bird species, we determined the feeding guild from the Handbook of Birds of the World [13] or on-line sources (Table 1). The feeding guild was classified as frugivorous (fruit-eater), granivorous (seed/grain-eater), insectivorous (insect-eater), carnivorous (feeding on non-insect animals), and any combinations of these. We also included the global conservation status of species published by the International Union for Conservation of Nature (IUCN) Red List of Threatened Species [14], while the regional rating of conservation status was based on [15]. Besides that, the enlistment of species under the Malaysian Wildlife Conservation Act 2010 (Act No. 716) which serves protection, conservation, and management of wildlife was also recorded.

\section{Data Analysis}

The difference in species richness between the BFR and the developed areas of Tanjung Malim was analyzed based on Chi-Square $\left(\mathrm{X}^{2}\right)$ analysis. $\mathrm{H}_{0}$ stated that there was no difference in species richness between the habitats while $\mathrm{H}_{1}$ stated vice versa. We compared the similarity of species compositions between BFR and developed areas of Tanjung Malim by using Jaccard Index. The formula of Jaccard Index is:

$$
\text { Jaccard Index }=\frac{\text { Number of species in common in BFR and developed areas }}{\text { Total number of species in both BFR and developed areas }}
$$

The Jaccard Index will produce value between 0 and 1, where 0 indicates no similarity in species composition between BFR and developed areas of Tanjung Malim, while 1 indicates identical sets of species composition. Migrant species are excluded during this analysis.

\section{RESULTS}

In total, we recorded 13 species of birds belonging to 11 families at the BFR, and 15 species comprising of 12 families in the developed areas of Tanjung Malim (Table 1). Chi-square analysis found that there was no significant difference in species richness between the BFR and the developed areas of Tanjung Malim $\left(\mathrm{X}^{2}(\mathrm{df}=1, \mathrm{~N}=28)=0.1429, p\right.$ - value $\left.=0.05\right)$. Nevertheless, the Jaccard Index analysis yield a value of 0.08 which indicates a very low similarity of bird species composition between the two habitats.

The most represented family in BFR was Megalaimidae which composed of two species i.e. red-throated barbet (Psilopogon mystacophanos) and yellow-crowned barbet (Psilopogon henricii). Family Turdidae at BFR also consisted of two species (orange-headed thrush (Geokichla citrina) and white-rumped shama (Kittacincla malabarica)). Meanwhile, the developed areas of Tanjung Malim were dominated by Columbidae family as represented by pink-necked pigeon, rock pigeon, and zebra dove, and followed by Sturnidae with two species (Asian glossy starling and common myna). Similar to BFR, the rest of the bird families composed of one species each. Species that occur at both habitats were greater racquet-tailed drongo and Asian glossy starling. While most birds inhabiting developed areas were detected by observation, detection of forest birds depended more on bird vocalization due to limited vision in dense vegetation. 
Table 1. Bird species at Behrang Forest Reserve and developed areas of Tanjung Malim in Muallim, Perak.

\begin{tabular}{|c|c|c|c|c|c|c|c|c|c|c|c|}
\hline \multirow[t]{2}{*}{ Family } & \multirow[t]{2}{*}{ Common name } & \multirow[t]{2}{*}{ Species name } & \multirow{2}{*}{$\begin{array}{c}\text { Detection } \\
\text { method }^{\mathrm{a}}\end{array}$} & \multicolumn{5}{|c|}{ Feeding guild } & \multicolumn{2}{|c|}{ Conservation status } & \multirow{2}{*}{$\begin{array}{l}\text { WCA } \\
2010\end{array}$} \\
\hline & & & & $\mathbf{F}$ & $\mathbf{G}$ & I & $\mathbf{C}$ & $\mathbf{N}$ & $\begin{array}{r}\text { IUCN } \\
2018^{b}\end{array}$ & $\begin{array}{c}\text { Wells } \\
(2010)^{c}\end{array}$ & \\
\hline \multicolumn{12}{|c|}{ Behrang Forest Reserve } \\
\hline Bucerotidae & Rhinoceros hornbill & Buceros rhinoceros & $\mathrm{V}$ & 1 & & 1 & I & & VU & VU/EN & $\mathrm{TP}$ \\
\hline Columbidae & Mountain imperial pigeon & Ducula badia & $\mathrm{O}$ & 1 & & & & & $\mathrm{LC}$ & $\mathrm{LC} / \mathrm{NT}$ & $\mathrm{TP}$ \\
\hline Cuculidae & Indian cuckoo & Cuculus micropterus & $\mathrm{V}$ & / & & l & & & $\mathrm{LC}$ & VU & $\mathrm{TP}$ \\
\hline Dicaeidae & Crimson breasted flowerpecker & Prionochilus percussus & M & / & & & & & $\mathrm{LC}$ & $\mathrm{LC}$ & $\mathrm{TP}$ \\
\hline Dicruridae & Greater racquet-tailed drongo & Dicrurus paradiseus & $\mathrm{O}$ & & & 1 & / & / & $\mathrm{LC}$ & $\mathrm{LC}$ & $\mathrm{TP}$ \\
\hline Eurylaimidae & Black-and-yellow broadbill & Eurylaimus ochromalus & $\mathrm{V}$ & & & / & & & NT & NT & $\mathrm{TP}$ \\
\hline Irenidae & Asian fairy-bluebird & Irena puella & $\mathrm{V}$ & / & & & & & $\mathrm{LC}$ & NT/VU & $\mathrm{TP}$ \\
\hline \multirow[t]{2}{*}{ Megalaimidae } & Red-throated barbet & Psilopogon mystacophanos & $\mathrm{V}$ & / & & / & & & NT & VU & $\mathrm{TP}$ \\
\hline & Yellow-crowned barbet & Psilopogon henricii & $\mathrm{V}$ & / & & & & & NT & VU & $\mathrm{TP}$ \\
\hline Muscicapidae & Grey-headed canary-flycatcher & Culicicapa ceylonensis & $\mathrm{V}$ & & & / & & & $\mathrm{LC}$ & NT & $\mathrm{TP}$ \\
\hline Sturnidae & Asian glossy starling & Aplonis panayensis & $\mathrm{O}$ & / & & / & & / & $\mathrm{LC}$ & $\mathrm{LC}$ & - \\
\hline \multirow[t]{2}{*}{ Turdidae } & Orange-headed thrush* & Geokichla citrina & M & / & l & / & & & $\mathrm{LC}$ & NT/VU & $\mathrm{TP}$ \\
\hline & White-rumped shama & Kittacincla malabarica & $\mathrm{V}$ & l & & l & & & $\mathrm{LC}$ & NT/VU & HS \\
\hline
\end{tabular}


Table 1 (continued)

\begin{tabular}{|c|c|c|c|c|c|c|c|c|c|c|c|}
\hline \multirow[t]{2}{*}{ Family } & \multirow[t]{2}{*}{ Common name } & \multirow[t]{2}{*}{ Species name } & \multirow{2}{*}{$\begin{array}{c}\text { Detection } \\
\text { method }^{\mathrm{a}}\end{array}$} & \multicolumn{5}{|c|}{ Feeding guild } & \multicolumn{2}{|c|}{ Conservation status } & \multirow{2}{*}{$\begin{array}{l}\text { WCA } \\
2010\end{array}$} \\
\hline & & & & $\mathbf{F}$ & G & I & $\mathrm{C}$ & $\mathbf{N}$ & $\begin{array}{r}\text { IUCN } \\
2018^{b}\end{array}$ & $\begin{array}{c}\text { Wells } \\
(2010)^{\mathrm{c}}\end{array}$ & \\
\hline \multicolumn{12}{|c|}{ Developed areas of Tanjung Malim } \\
\hline Aegithinidae & Common iora & Aegithina tiphia & $\mathrm{O}$ & & & I & & & $\mathrm{LC}$ & $\mathrm{LC}$ & $\mathrm{TP}$ \\
\hline Bucerotidae & Oriental pied hornbill & Anthracoceros albirostris & $\mathrm{O}$ & / & & / & / & & $\mathrm{LC}$ & NT & $\mathrm{TP}$ \\
\hline \multirow[t]{3}{*}{ Columbidae } & Pink-necked pigeon & Treron vernans & $\mathrm{O}$ & / & & & & & $\mathrm{LC}$ & $\mathrm{LC}$ & HS \\
\hline & Rock pigeon & Columba livia & $\mathrm{O}$ & & / & l & & & $\mathrm{LC}$ & $\mathrm{LC}$ & $\mathrm{CS}$ \\
\hline & Zebra dove & Geopelia striata & $\mathrm{O} / \mathrm{V}$ & & / & l & & & $\mathrm{LC}$ & $\mathrm{LC}$ & - \\
\hline Dicruridae & Greater racquet-tailed drongo & Dicrurus paradiseus & $\mathrm{O}$ & & & l & l & l & $\mathrm{LC}$ & $\mathrm{LC}$ & $\mathrm{TP}$ \\
\hline Estrildidae & Scaly-breasted munia & Lonchura punctulata & $\mathrm{O}$ & & l & l & & & LC & $\mathrm{LC}$ & HS \\
\hline Laniidae & Brown shrike & Lanius cristatus & $\mathrm{O}$ & & & l & l & & $\mathrm{LC}$ & $\mathrm{LC}$ & $\mathrm{TP}$ \\
\hline Hirundinidae & Barn swallow* & Hirundo rustica & $\mathrm{O}$ & & & l & & & $\mathrm{LC}$ & $\mathrm{LC}$ & $\mathrm{TP}$ \\
\hline Motacilidae & Paddyfield pipit & Anthus fufulus & $\mathrm{O}$ & & & l & & & $\mathrm{LC}$ & $\mathrm{LC}$ & - \\
\hline Muscicapidae & Oriental magpie-robin & Copsychus saularis & $\mathrm{O}$ & & & l & & & $\mathrm{LC}$ & $\mathrm{LC} / \mathrm{NT}$ & HS \\
\hline Oriolidae & Black-naped oriole & Oriolus chinensis & $\mathrm{O}$ & l & & l & & & $\mathrm{LC}$ & $\mathrm{LC}$ & $\mathrm{TP}$ \\
\hline Passeridae & Eurasian tree sparrow & Passer montanus & $\mathrm{O} / \mathrm{V}$ & & / & / & & & $\mathrm{LC}$ & $\mathrm{LC}$ & - \\
\hline
\end{tabular}


Table 1 (continued)

\begin{tabular}{|c|c|c|c|c|c|c|c|c|c|c|c|}
\hline \multirow[t]{2}{*}{ Family } & \multirow[t]{2}{*}{ Common name } & \multirow[t]{2}{*}{ Species name } & \multirow{2}{*}{$\begin{array}{c}\text { Detection } \\
\text { method }^{\mathrm{a}}\end{array}$} & \multicolumn{5}{|c|}{ Feeding guild } & \multicolumn{2}{|c|}{ Conservation status } & \multirow{2}{*}{$\begin{array}{l}\text { WCA } \\
2010^{d}\end{array}$} \\
\hline & & & & $\mathbf{F}$ & $\mathbf{G}$ & I & $\mathbf{C}$ & $\mathbf{N}$ & $\begin{array}{r}\text { IUCN } \\
2018^{b}\end{array}$ & $\begin{array}{c}\text { Wells } \\
(2010)^{\mathrm{c}}\end{array}$ & \\
\hline \multicolumn{12}{|c|}{ Developed areas of Tanjung Malim } \\
\hline Pycnonotidae & Yellow-vented bulbul & Pycnonotus goiavier & $\mathrm{O}$ & I & 1 & 1 & & 1 & $\mathrm{LC}$ & $\mathrm{LC}$ & - \\
\hline \multirow[t]{2}{*}{ Sturnidae } & Asian glossy starling & Aplonis panayensis & $\mathrm{O} / \mathrm{M}$ & / & & / & & / & $\mathrm{LC}$ & $\mathrm{LC}$ & - \\
\hline & Common myna & Acridotheres tristis & $\mathrm{O}$ & & / & l & & & $\mathrm{LC}$ & $\mathrm{LC}$ & - \\
\hline
\end{tabular}

a Detection method (O: visual observation, V: vocalization, M: capture using mist net); Feeding guild (F: frugivorous, G: granivorous, I: insectivorous, C: carnivorous, N: nectarivorous)

${ }^{b}$ Global rating of conservation status based on IUCN 2018 (LC: least concern, NT: near threatened, VU: vulnerable)

${ }^{\mathrm{c}}$ Regional rating of conservation status based on [15] (LC: least concern, NT: near threatened; VU: vulnerable; EN: endangered; CR: critically endangered; /: bordering to)

${ }^{\mathrm{d}}$ WCA 2010 (TP: totally protected species, HS: hunted species, CS: controlled species)

*Migrant 
The bird species in Muallim belonged to different types of feeding guilds i.e. frugivorous, insectivore, or the combinations with granivore, nectarivore, and carnivore (Figure 2). Forest birds were mainly frugivores (31\%), frugivores-insectivores (23\%), and insectivores $(15 \%)$. On the other hand, only $7 \%$ (one species) of birds in the developed areas were frugivores, $20 \%$ were insectivores-granivores and $7 \%$ were insectivores.

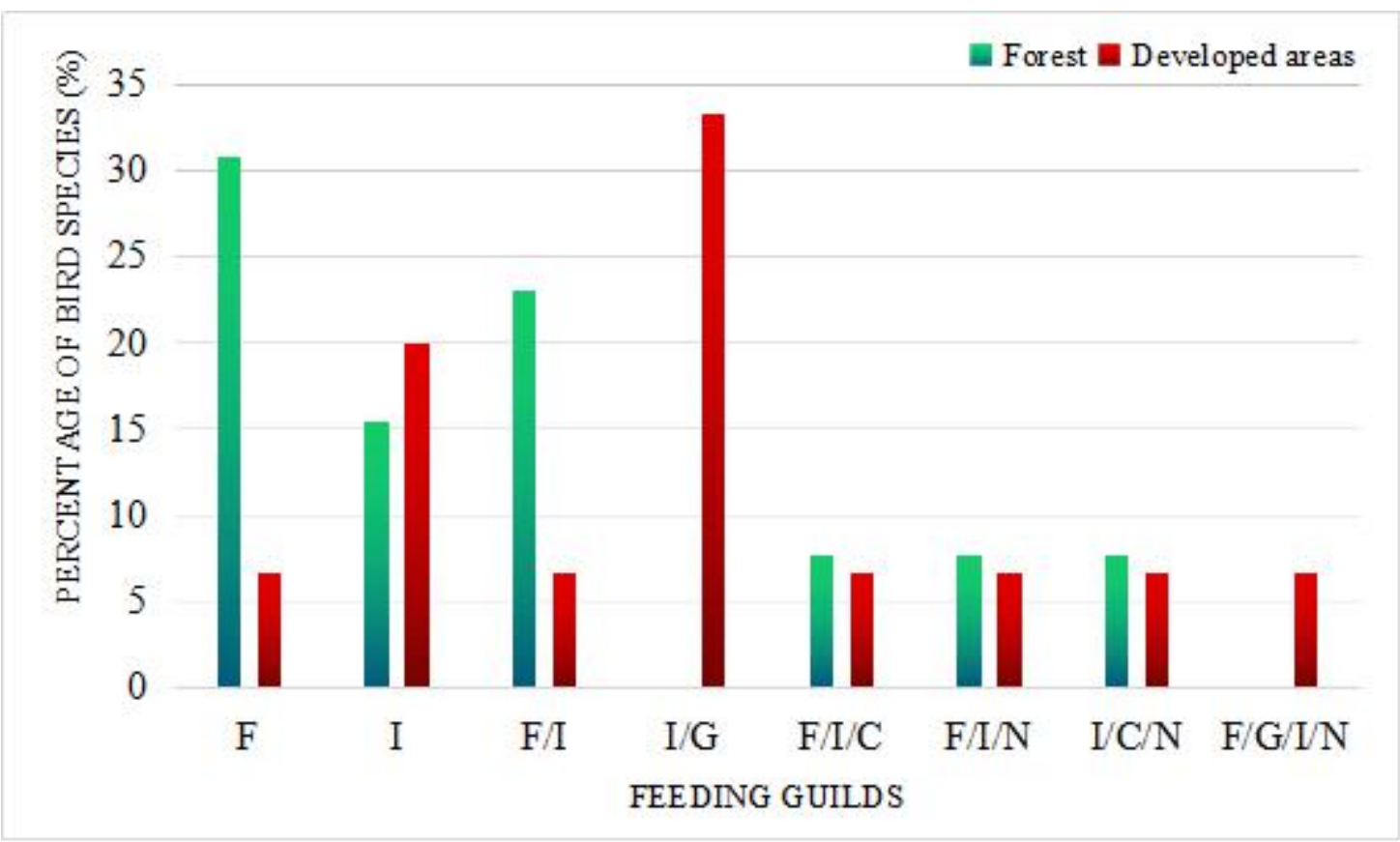

Figure 2. Percentage of birds with different feeding guilds from forest and developed areas of Tanjung Malim in Muallim, Perak (F: frugivore, G: granivore, I: insectivore, C: carnivore, N: nectarivore, / indicates combination of feeding guilds).

Most birds in Muallim were categorized as 'least concern' species following [14] which indicates that these species are not under the major focus for conservation at global level. However, several species such as black-and-yellow broadbill, red-throated barbet, and yellow-crowned barbet were classified 'near threatened', while the rhinoceros hornbill was even categorized as 'vulnerable'. These four species used forest as their natural habitat. Meanwhile, conservation status assessment at regional level showed that 10 out of 13 species in BFR were either near threatened, vulnerable, or endangered, whereas the developed areas bore two near threatened species out of 15 urbanized species.

\section{DISCUSSION}

Our study found that both BFR and the developed areas of Tanjung Malim housed similar number of bird species (13 species of birds at the BFR and 15 species in the developed areas of Tanjung Malim). However, each habitat type generally consisted of different species, except for the greater racquet-tailed drongo and Asian glossy starling which occured at both habitats. Such findings may probably cause by the different food resources present in each habitat. According to our results, fruits are important food items for forest birds whereas insects and seed/grains are more important or bird communities in developed areas. Insects are the major food resources for birds from both forest and developed areas. [16] stated that developed environments favor birds with insectivorous diet, but a review by [17] found that urban dwellers are diet generalist, granivores or non-insectivores. These heterogenous results warrant for further investigations. 
Only two out of 13 species detected in forests were also found in the developed areas. These species, the greater racquet-tailed drongo and Asian glossy starling, have the combinations of three feeding guilds instead of only two combinations like most of the forest species (Table 1). Greater racquet-tailed drongos are primarily insectivores but they also feed on small vertebrates and nectar [18] whereas Asian glossy starlings feed primarily on fruits and insects, as well as nectar as an alternative diet [19]. Having a wider range of feeding niche may probably help birds to occupy multiple types of habitats including developed areas. A review by [20] which attempted to identify processes that shape the diversity of urban fauna revealed that omnivore is an important trait for urban birds. Nevertheless, rhinoceros hornbills, which were absent in the developed areas, were omnivores because they had the combinations of three feeding guilds. Yet, they did not occur in both habitats. Such results indicate that it may not be necessary for birds to have a broad range (combinations of feeding guilds) of feeding niche to survive in developed areas, similar to what was suggested by [16].

Therefore, feeding habit may not be the only factor that determines the occurrence of a species in a habitat, thus, other intrinsic factors such as sedentariness, nest type $[16,21,22]$, and ability to cope with proximity of humans [17] may also influence the occurrence of birds in different environments. This idea is aligned with [20] which stated that it is rare that a single factor can be used to separate between birds that are well adapted to developed environments and those that do not.

\section{CONCLUSION}

In general, our study suggests that different habitat types allow different species of bird to thrive. The presence of species in a habitat is not only influenced by extrinsic factor which is the characteristics of the habitat, but also intrinsic factors such as feeding habit and the ability of birds to utilize resources in the environments. Our study suggests that being insectivores and granivores may give leverage for birds to perform well in developed environments. Developed areas are suitable to support numbers of species, but natural environments remained as essential habitats for non-urban species particularly the frugivorous. Our study is limited in terms of the number of sampling locations and surveys conducted which affects the overall species recorded. Thus, the findings of this study give preliminary insight into how urban bird communities are being shaped. We recommend that further studies should be conducted within a greater range of geographical areas and over a longer period to better understand the tropical bird community assemblages in the urbanizing world.

\section{REFERENCES}

[1] Grimm, N. B., Faeth, S. H., Golubiewski, N. E., Redman, C. L., Wu, J., Bai, X., \& Briggs, J. M. (2008). Global change and the ecology of cities. Science, 319(5864), 756-760.

[2] Liu, Z., He, C., Zhou, Y., \& Wu, J. (2014). How much of the world's land has been urbanized, really? A hierarchical framework for avoiding confusion. Landscape Ecology, 29(5), 763-771.

[3] Seto, K. C., Güneralp, B., \& Hutyra, L. R. (2012). Global forecasts of urban expansion to 2030 and direct impacts on biodiversity and carbon pools. Proceedings of the National Academy of Sciences, 109(40), 16083-16088.

[4] McKinney, M. L. (2008). Effects of urbanization on species richness: A review of plants and animals. Urban Ecosystems, 11(2), 161-176.

[5] Sol, D., Lapiedra, O., \& González-Lagos, C. (2013). Behavioural adjustments for a life in the city. Animal behaviour, 85(5), 1101-1112.

[6] Hedblom, M., \& Murgui, E. (2017). Urban bird research in a global perspective. In Ecology and Conservation of Birds in Urban Environments (pp. 3-10). Springer, Cham.

[7] Amos, J.N., Balasubramaniam, S., Grootendorst, L., Harrisson, K.A., Lill, A., Mac Nally, R., Pavlova, A., Radford, J.Q., Takeuchi, N., Thomson, J.R. \& Sunnucks, P. (2013). Little evidence that condition, stress indicators, sex ratio, or homozygosity are related to landscape or habitat attributes in declining woodland birds. Journal of avian biology, 44(1), 45-54. 
[8] Ministry of Water, Land and Natural Resources. (2019, July 1). https://www.mybis.gov.my/one/. Behrang Water Catchment Forest. Retrieved from mybis.gov.my/pa/190

[9] Birdeye (2019, July 1). Birds of Peninsular Malaysia Sound Collection. Retrieved from http://www.birdseyebirding.com/shop/audio/bird-sounds-of-malaysia/

[10] Jeyarajasingam, A. (2012). A field guide to the birds of Peninsular Malaysia and Singapore. Oxford University Press.

[11] Mohamed Zakaria Hussin \& Muhammad Nawaz Rajpar. (2014). Birds of wetlands in Peninsular Malaysia. Selangor: Universiti Putra Malaysia Press

[12] Robson, C. (2015). Birds of South-East Asia: Concise Edition. Bloomsbury Publishing.

[13] Lynx Edicions (2019, July 1). Handbook of Birds of the World Alive. Retrieved from https://www.hbw.com/

[14] IUCN (2019, July 1). The IUCN red list of threatened species. Retrived from https://www.iucnredlist.org/

[15] Wells, D. (2019, July 1). Common Iora (Aegithina tiphia). In: del Hoyo, J., Elliott, A., Sargatal, J., Christie, D.A. \& de Juana, E. (eds.). Handbook of the Birds of the World Alive. Lynx Edicions, Barcelona. Retrieved from https://www.hbw.com/node/58074

[16] Evans, K. L., Chamberlain, D. E., Hatchwell, B. J., Gregory, R. D., \& Gaston, K. J. (2011). What makes an urban bird?. Global Change Biology, 17(1), 32-44.

[17] Møller, A. P. (2014). Behavioural and ecological predictors of urbanization. Avian urban ecology, 54-68.

[18] Rocamora, G., Yeatman-Berthelot, D. \& de Juana, E. (2019, July 1). Greater Racquet-tailed Drongo (Dicrurus paradiseus). In: del Hoyo, J., Elliott, A., Sargatal, J., Christie, D.A. \& de Juana, E. (eds.). Handbook of the Birds of the World Alive. Lynx Edicions, Barcelona. Retrieved from https://www.hbw.com/node/60574

[19] Craig, A. \& Feare, C. (2019, July 1). Asian Glossy Starling (Aplonis panayensis). In: del Hoyo, J., Elliott, A., Sargatal, J., Christie, D.A. \& de Juana, E. (eds.). Handbook of the Birds of the World Alive. Lynx Edicions, Barcelona. (retrieved from https://www.hbw.com/node/60843

[20] Aronson, M.F., Nilon, C.H., Lepczyk, C.A., Parker, T.S., Warren, P.S., Cilliers, S.S., Goddard, M.A., Hahs, A.K., Herzog, C., Katti, M. and La Sorte, F.A. (2016). Hierarchical filters determine community assembly of urban species pools. Ecology, 97(11), 2952-2963.

[21] Croci, S., Butet, A., \& Clergeau, P. (2008). Does urbanization filter birds on the basis of their biological traits. The Condor, 110(2), 223-240.

[22] Lim, H.C., Sodhi, N.S., 2004. Responses of avian guilds to urbanisation in a tropical city. Landscape Urban Plann. 66, 199-215. 